\title{
Abstracts
}

\section{On the Meanings of Democracy}

Jean-Luc Nancy

'On the Meanings of Democracy' points to the fragility and contested meanings of 'democracy'. Once 'the assurance is given that "democracy" is the only kind of political regime that is acceptable to an adult, emancipated population which is an end in itself, the very idea of democracy fades and becomes blurred and confusing'. Such 'widespread lack of clarity' gave rise to Europe's 'totalitarian' regimes. It is claimed that 'it is impossible to be simply a "democrat" without questioning what this really means', and that to ignore the conceptual difficulties is as 'dangerous as rejecting democracy completely'. A 'minimal argument or blueprint for an enquiry into the possible meanings' of the term is proposed. The implications of taking 'democracy', the word, 'to describe the exercising of political power by the people' are explored. The 'people' as a social group distinct from some 'other reputedly superior part, which dominates it', is distinguished from the 'people' taken to mean 'the whole'. In the first sense, 'democracy' is not a regime but an uprising against a regime or government. In the second sense, the 'political sovereignty of the people' signifies their 'self-constitution as a people'. Accounts of democracy that focus not so much on its 'political specificity' as on 'civil society' or the 'social bond' are then explored. The author concludes with a reflection on the relationship between democracy, 'modernity' and the scope, nature and place of politics.

Keywords: democracy; modernity; revolt; public; political

\section{Democratic Polities and Anti-democratic Politics \\ David Plotke}

What if anything should democratic polities do with respect to political forces and citizens who oppose democratic practices? One strategy is toleration, understood as non-interference. A second approach is repression, aimed at marginalizing or breaking up non-democratic political forces. I argue for a third approach: democratic states and citizens should respond to non-democratic political forces and ideas 
mainly through efforts at political incorporation. This strategy can protect democratic practices while respecting citizens' rights; its prospects are enhanced by the diverse political composition of most contemporary anti-democratic projects and the integrative effects of democratic procedures.

Keywords: repression; toleration; anti-democratic politics; political incorporation; inclusion

\section{Democracy's Equality, Freedom, and Help}

Ted Honderich

Democracy has been justified as the political system whose citizens are sovereign, which is to say most free or most equal in their political experience, participation or consent, and most likely to be benefited by economic freedoms. Most importantly, democracy is recommended as that form of government which gets things more right than any other form of government. But this traditional view, and also more recent qualifications of this view, is simply inadequate, refuted and rendered nonsensical by very real electoral, wealth, income and power inequalities in democratic societies. Nevertheless, it is this kind of hierarchic democracy, like those of the United States and the United Kingdom, whose systems of government are exactly not true to the idea that two heads are better than one and more heads better than two, which reaches to judgements about Palestine, 9/11, Iraq, 7/7 and about all that is to come after those things.

Keywords: democracy; equality; freedom; decision-making; majoritarianism

\section{Theorizing Democracy and Violence: The Case of Northern Ireland} Adrian Little

This article examines the concept of violence in contemporary political theory focusing in particular on the possibility of rethinking the relationship between violence and democracy. Rather than seeing democracy and violence as contrasting concepts, it argues that democratic societies have always been founded on the basis of violent engagement at some level. And, of course, the modern state has always claimed the legitimate use of force as a key ingredient in its authority. The article contends that many contemporary democratic discourses have lost sight of the integral relationship between 
democracy and violence. Indeed it is frequently the case that discourses of democracy are couched in ethical terms as the obverse of violence. Ironically, this trend is often most apparent where societies are either making a transition to democracy or where a process of conflict transformation is taking place. The limitations of these approaches for our understanding of violence and democracy will be outlined in this article through an examination of contemporary political developments in Northern Ireland.

Keywords: violence; democracy; Northern Ireland; reconciliation; terror

\section{Nonviolent Political Action and the Limits of Consent} Iain Atack

The consent theory of power, whereby ruling elites depend ultimately on the submission, cooperation and obedience of the governed as their source of power, is often linked to debates about the effectiveness of non-violent political action. According to this theory, ruling elites depend ultimately on the submission, cooperation and obedience of the governed as their source of power. If this cooperation is withdrawn, then this power is undermined. Iain Atack outlines this theory and examines its strengths and weaknesses. Atack argues that incorporating the insights of other theories of power, such as Gramsci's theory of hegemony and Foucault's views on 'micro-power', can provide us with a more sophisticated understanding of both the effectiveness and the limits of nonviolent political action than the consent theory of power. Gramsci's contribution deepens the analysis in terms of our understanding of the origins of individual consent in the context of larger economic and political structures, while Foucault adds a different dimension, in that his micro-approach emphasizes the ubiquity and plurality of power, rather than its embodiment or reification in large-scale structures.

Keywords: consent; power; non-violent political action; submission; Foucault; Gramsci; hegemony; resistance

\section{The Grammars of 'Power': Between Contestation and Mediation Mark Rigstad}

In light of the pragmatic aspirations of ordinary language philosophy, this essay critically examines the competing grammatical strictures that are often set forth within the theoretical discourse of 'power'. It 
repudiates both categorically appraisive employments of 'power' and the antithetical urge to fully operationalize the concept. It offers an attenuated defense of the thesis that 'power' is an essentially contestable concept, but rejects the notion that this linguistic fact stems from conflict between antipodal ideological paradigms. Careful attention to the ordinary pragmatics of power-language evinces the prospects for integrating various context-specific aspects of power and mediating between traditionally divergent theoretical frameworks.

Keywords: power; operationalism; incommensurability; discourse analysis; ordinary language philosophy 
Volume 53, 2006 : Theoria Referees

\section{The Editors wish to express their appreciation to the following individuals who assisted the refereeing process for 2006}

Bruce Ackerman
Richard Aldrich
Rod Alence
Michael Apple
Zehra Arat
David Archard
Tarak Barkawi
Rachel Barney
Ian Beckett
Duncan Bell
David Benatar
Solomon Benatar
Joseph Bendersky
Lorraine Besser-Jones
Cristina Bicchieri
Silvia Caporale Bizzini
Charles Blattberg
Fred Block
Ken Booth
Richard Bourke
Joseph Boyle
Gerard Bradley
Chris Brown
Allen Buchanan
Peter Burke
Peter Busch
David Campbell
Martin Carnoy
Patrick Chabal
G. A. Cohen
Joshua Cohen
John Collier
Jean Comaroff
William Connolly
Garry Crawford
Jenifer Crawford
Tomas Englund
Neta Crawford
Angela Creager
Clayton Crockett
Frank Cunningham
Fred D'Agostino
Fred Dallmayr
Norman Daniels
Maurizio d'Entreves
Steve de Gruchy
Lucy Delap
Marguerite Deslauriers
Michael Dillon
Chris Dolan
John Dryzek
Mark Duffield
Margaret Duncan

Steven Epstein

Martyn Evans

Richard Falk

Torkel Falkenberg

Colin Farrelly

Don Foster

Lawrence Freedman

Joshua Gamson

J. L. A. Garcia

William Gay

Margaret Gilbert

Nils Petter Gleditsch

Charles Griswold

John Gunnell

Mark Haugaard

Patrick Hayden

Virginia Held

Barry Hindess

John Horton

Susan Hurley

Laurence Iannaccone

Michael Jackson

Vaughn John

Susanne Karstedt

Joan Kaufman

John Kelsay

Jean-François Kervegan

Rachel King

Will Kymlicka

Lance Lachenicht

Jacqueline Laing

Gabriel Richardson Lear

Peter Lentini

Andrew Levine

Michael Levine

John Lie

Ronnie Lipschutz

Rodney Loeppky

Leslie London

Hennie Lötter

Tim Luke

Eric MacGilvray

Arthur Madigan

Matt Matravers

Philippe Mayaud

Peter Mayer

Marina McCoy

Alison McIntyre

Jeff McMahan

Maria Merritt

Thad Metz

Ces Moore

Margaret Moore

Jonathan Moreno

Herfried Münkler

Mark Murphy

Brigitte Nacos

Andrew Nash
Piet Naudé

Phillimon Ndubani

Sibongile Nene

Peter Neumann

Saul Newman

Joseph Nye

Geoff O'Brien

Ian O'Flynn

Michael O'Keefe

Shane O'Neill

Mark Olssen

Ido Oren

David Papineau

Julie Parle

Brian Penrose

Daniel Polsky

Mark Poster

Leonhard Praeg

Gail Presbey

Lee Quinby

Sabrina Ramet

William Rasch

Fred Rauscher

Julian Reid

Deborah Roberts

Steven Robins

Jennifer Robinson

Richard Rorty

Vernon Rosario

Robert Rotberg

David-Hillel Rubin

John Sanbonmatsu

Marian Sawer

Robin May Schott

Annette Seegers

Kenneth Shepsle

Kurt Shillinger

Jane Slaughter

Dennis Smith

Rogers Smith

Dale Snauwaert

Bent Sørensen

Jeff Spinner-Halev

Liz Stanley

Jeremy Sugarman

Arpad Szakolczai

Patricia Thomas

James Tully

Raimo Tuomela

Robert van Krieken

Samantha Vice

Michael Walzer

Doug Wassenaar

Leonard Weinberg

Stephen White

Andrew Williams

Robert Paul Wolff

Patricia Wrightson 


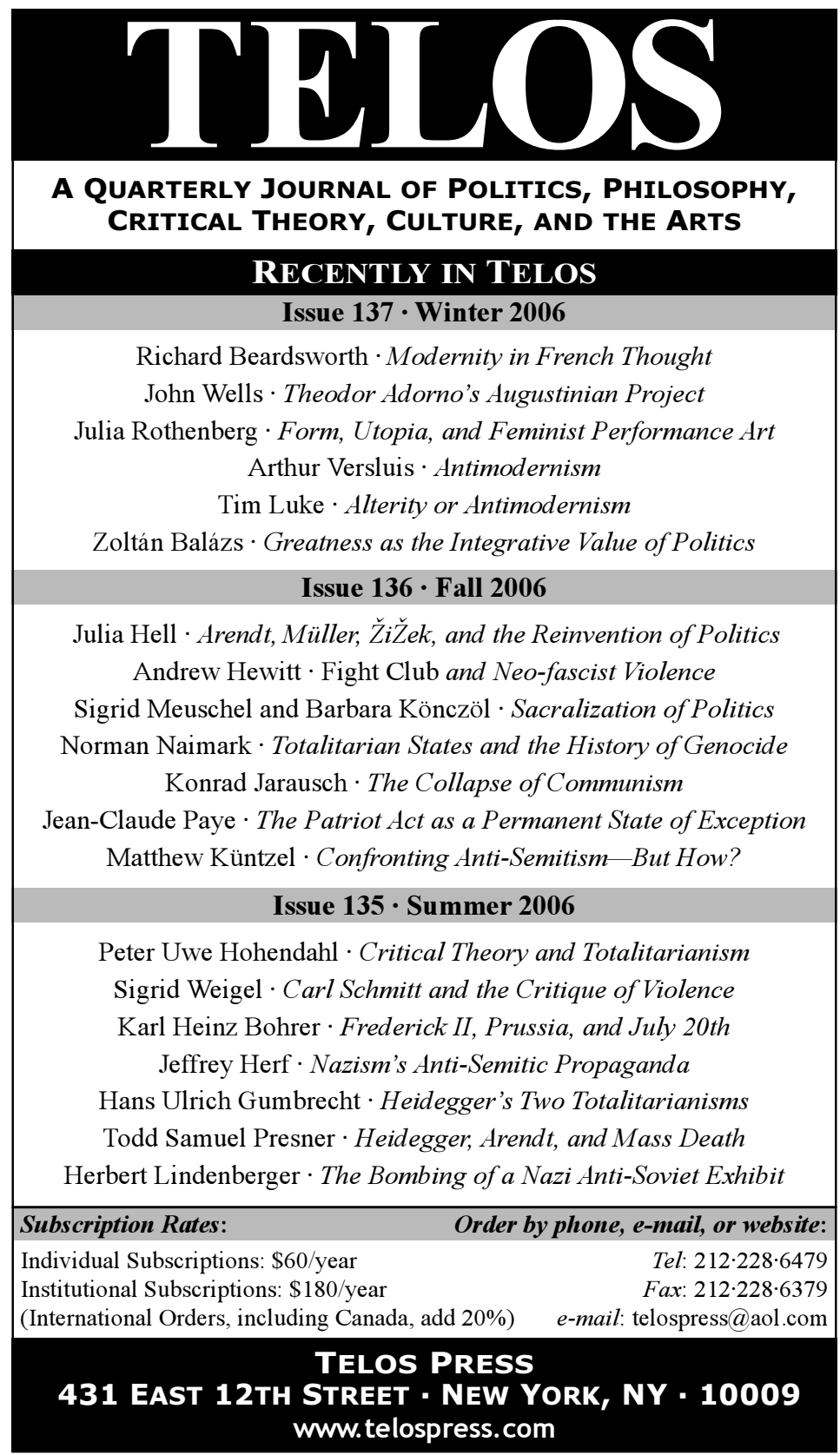

